\title{
Hubungan Pengetahuan Perawat Dalam Melakukan Perencanaan Keperawatan di Rumah Sakit \\ Christin Butar Butar \\ christinbutarbutar19@gmail.com
}

\section{Latar Belakang}

Dalam keperawatan terdapat perencanaan/keperawatan yang menjadi pedoman perawat dalam memecahkan masalah klien. Proses keperawatan adalah suatu pendekatan dalam pemecahan masalah, sehingga perawat dapat merencanakan dan memberikan asuhan keperawatan (Potter and Perry, 1997). Proses keperawatan akan sangat membantu perawat dalam merencanakan asuhan keperawatan yang tepat dan berkualitas. Perawat sebagai suatu profesi merupakan bagian dari tim kesehatan yang bertanggungjawab membantu klien sebagai individu, keluarga, dan masyarakat baik dalam kondisi sehat maupun sakit. Seiring perkembangan keperawatan, keilmuan dalam praktik keperawatan pun turut berkembang.

Perencanaan merupakan suatu petunjuk tertulis yang menggambarkan secara tepat rencana tindakan keperawatan yang dilakukan terhadap klien sesuai dengan kebutuhannya berdasarkan diagnosis keperawatan. Tujuan dari dituliskannya kajian ini adalah untuk memberi informasi kepada pembaca khususnya para perawat atau yang sedang mengikuti pendidikan keperawatan mengenai pentingnya perancanaan asuhan keperawatan sehingga asuhan keperawatan dapat dengan mudah dan cepat serta tepat untuk dilaksanakan

Kata Kunci : Perencanaan Keperawatan, Implementasi,

\section{Metode}

Metode penelitian yang digunakan adalah metode research dan analisis dari berbagai sumber seperti buku teks, buku referensi jurnal, e-book, dan juga membandingkan beberapa jurnal yang berhubungan dengan peran perawat dalam pelayan perencanaan keperawatan dalam hal melakukan implementasi keperawatan . diterapkan yang berfungsi untuk menggambarkan objek yang diteliti melalui sampel yang terkumpul dari data yang ada. 


\section{Hasil}

Perencanaan Keperawatan adalah sebuah proses penyusunan berbagai intervensi keperawatan yang dibutuhkan untuk mencegah, menurunkan, serta mengurangi masalah-masalah klien. Perencanaan ini adalah langkah ketiga dalam membuat suatu proses keperawatan. Perencanaan adalah merupakan bagian dari fase pengorganisasian dalam proses keperawatan sebagai pedoman untuk mengarahkan tindakan keperawatan dalam usaha membantu, meringankan, memecahkan masalah atau untuk memenuhi kebutuhan klien

Perencanaan keperawatan berkaitan erat dengan implemetasi keperawatan, dimana Implementasi adalah tahap ketika perawat mengaplikasikan rencana asuhan keperawatan ke dalam bentuk intervensi keperawatan guna membantu klien mencapai tujuan yang telah ditetapkan (Asmadi, 2008).

\section{Pembahasan}

Pengertian Perencanaan Keperawatan

Perencanaan Keperawatan adalah sebuah proses penyusunan berbagai intervensi keperawatan yang dibutuhkan untuk mencegah, menurunkan, serta mengurangi masalahmasalah klien. Perencanaan ini adalah langkah ketiga dalam membuat suatu proses keperawatan. Perencanaan adalah merupakan bagian dari fase pengorganisasian dalam proses keperawatan sebagai pedoman untuk mengarahkan tindakan keperawatan dalam usaha membantu, meringankan, memecahkan masalah atau untuk memenuhi kebutuhan klien.Suatu perencanaan yang tertulis dengan baik akan memberi petunjuk dan arti pada asuhan keperawatan karena perencanaan adalah sumber informasi bagi semua yang terlibat dalam asuhan keperawatan klien. Perencanaan merupakan suatu petunjuk tertulis yang menggambarkan secara tepat rencana tindakan keperawatan yang dilakukan terhadap klien sesuai dengan kebutuhannya berdasarkan diagnosis keperawatan. 
Langkah Langkah Merumuskan Rencana

1. Menentukan Prioritas Masalah

Penetapan prioritas adalah penyusunan urutan diagnosis keperawatan/masalah klien dengan menggunakan tingkat kepentingan untuk memperoleh tahapan intervensi keperawatan yang dibutuhkan (Hendry dan Walker, 2004). Bersama klien, anda akan memilih prioritas berdasarkan kedaruratan masalah, keselamatan dan keinginan klien, sifat terapi dan hubungan anatar-diagnosis. Berdasarkan kepentingannya, prioritas dapat dikategorikan menjadi :

1. Prioritas Tinggi : prioritas yang mencerminkan situasi yang mengancam kehidupan (nyawa seseorang) sehingga perlu dilakukan tindakan terlebih dahulu

2. Prioritas Sedang : prioritas ini menggambarkan situasi yang tidak gawat dan tidak mengancam kehidupan klien

3. Prioritas Rendah : prioritas yang menggambarkan situasi yang tidak berhubungan langsung dengan prognosis dari suatu penyakit yang secara spesifik.

2. Menuliskan Kriteria Evaluasi (Hasil) / (Outcomes)

Tujuan klien dan tujuan keperawatan adalah standar atau ukuran yang digunakan untuk mengevaluasi kemajuan klien atau keterampilan perawat. Tujuan klien seperti halnya semua komponen proses perencanaan asuhan bersifat dinamis, oleh karena itu tujuan pasien dapat berubah dengan cepat. Pernyataan tujuan pasien yang spesifik dan indivisual merupakan hal yang penting digunakan untuk mengevaluasi respon pasien terhadap perawatan dan mengevaluasi keberhasilan rencana tindakan.

3. Memilih rencana / intervensi keperawatan

Tipe intervensi :

a. Intervensi perawat

Adalah respon perawat terhadap kebutuhan perawatan kesehatan dan diagnosa keperawatan klien. Kegiatan berhubungan dengan promosi kesehatan, mempertahankan atau menjaga kesehatan klien. Tipe intervensi ini dikategorikan menjadi tiga yaitu 1) Dependen 2) Interdependen dan 3) Independen. Intervensi ini tidak membutuhkan supervisi atau arahan orang lain, instruksi dokter atau profesi lainnya. Intervensi mencakup aktivitas kehidupan sehari- hari (ADL), penyuluhan kesehatan, promosi kesehatan dan konseling. 
b. Intervensi Dokter

Adalah respon dokter terhadap diagnosa medis dan perawat menyelesaikan instruksi tertulis dokter. Intervensi tidak selalu berada dalam praktik legal keperawatan tetapi intervensi tersebut berada dalam praktik keperawatan, bagi perawat untuk menyelesaikan instruksi tersebut. Contoh intervensi : medikasi, implementasi prosedur invasif, mengganti balutan dan mempersiapkan pemeriksaan diagnostik. Setiap intervensi dokter membutuhkan tanggung jawab spesifik dan pengetahuan keperawatan teknik spesifik.

c. Intervensi Kolaboratif

Adalah terapi yang membutuhkan pengetahuan, keterampilan dan keahlian khusus dari berbagai profesional keperwatan kesehatan.

Tahap-Tahap Implementasi :

1. Tahap persiapan Tahap ini meliputi; review antisipasi tindakan keperawatan, mengetahui hal yang mungkin timbul, mempersiapkan peralatan yang diperlukan, membuat lingkungan kondusif, mengiddentifikasi aspek hukum dan etik, dan intervensi.

2. Tahap Pelaksanaan a) mengkomunikasikan dan menginformasikan kepada klien tentang keputusantindakam keperawatan yang dilakukan oleh perawat. b) Beri kesempatan kepada klien untuk mengekspresikan perasaannya terhadap penjelasan yang telah diberika oleh perawat. c) mererapkan pengetahuan intelektual dan kemampuan hubungan antar manusia dan kemampuan teknis keperawatan dalam tindakan pelaksanaan keperawatan yang diberikan oleh perawat. d) Hal-hal yang perlu diperhatikan pada saat pelaksanaan tindakan adalah energi klien dan pencegahan kecelakaan, komplikasi, rasa aman, privasi, kondisi klien dan respon klien terhadap tindakan yang telah diberikan.

3. Tahap Terminasi Perawat memperhatikan respon klien terhadap tindakan keperawatan yang telah diberikan. Meninjau kemajuan klien dari tindakan keperawatan yang telah diberikan dan rapikan peralatan dan lingkungan klien dan lakukan terminasi. 
Perumusan Tujuan Dan Kriteria Hasil

Kriteria evaluasi atau hasil mempunyai ciri -ciri sebagai berikut :

1. Setiap kriteria hasil berhubungan dengan tujuan yang telah ditetapkan.

2. Hasil yang ditetapkan dalam kriteria hasil, memungkinkan untuk dicapai.

3. Setiap kriteria hasil adalah pernyataan satu hal yang spesifik.

4. Kriteria harus sekonkrit mungkin untuk memudahkan pengukuran.

5. Kriteria cukup besar atau dapat diukur. Hasilnya dapat dilihat dan didengar.

6. Kriteria menggunakan kata - kata positif bukan menggunakan kata negatif.

Pedoman penulisan kriteria hasil :

1. Berfokus pada klien.

2. Singkat dan jelas.

3. Dapat di observasi dan di ukur.

4. Ada batas waktu.

5. Ditentukan oleh perawat dan klien.

\section{Pengertian Implementasi}

Implementasi keperawatan adalah serangkaian kegiatan yang dilakukan oleh perawat untuk membantu klien dari masalah status kesehatan yang dihadapi kestatus kesehatan yang baik yang menggambarkan kriteria hasil yang diharapkan (Gordon, 1994, dalam Potter \& Perry, 1997).

Implementasi keperawatan adalah kategori dari perilaku keperawatan dimana tindakan yang diperlukan untuk mencapai tujuan dan hasil yang diperkirakan dari asuhan keperawatan dilakukan dan diselesaikan (Potter dan Perry, 2005)

Implementasi adalah tahap ketika perawat mengaplikasikan rencana asuhan keperawatan ke dalam bentuk intervensi keperawatan guna membantu klien mencapai tujuan yang telah ditetapkan (Asmadi, 2008). 


\section{Proses Implementasi}

1. Berdasarkan respons klien.

2. Berdasarkan ilmu pengetahuan, hasil penelitian keperawatan, standar pelayanan professional, hukum dan kode etik keperawatan.

3. Berdasarkan penggunaan sumber-sumber yang tersedia.

4. Sesuai dengan tanggung jawab dan tanggung gugat profesi keperawatan.

5. Mengerti dengan jelas pesanan-pesanan yang ada dalam rencana intervensi keperawatan

6. Harus dapat menciptakan

adaptasi dengan klien sebagai individu dalam upaya meningkatkan peran serta untuk merawat diri sendiri (Self Care)

7. Menekankan pada aspek pencegahan dan upaya peningkatan status kesehatan.

8. Dapat menjaga rasa aman, harga diri dan melindungi klien.

9. Memberikan pendidikan, dukungan dan bantuan.

10. Bersifat holistik.

11. Kerjasama dengan profesi lain.

12. Melakukan dokumentasi.

\section{Penutup (Kesimpulan)}

Perencanaan merupakan suatu petunjuk tertulis yang menggambarkan secara tepat rencana tindakan keperawatan yang dilakukan terhadap klien sesuai dengan kebutuhannya berdasarkan diagnosis keperawatan. Tujuan dari dituliskannya kajian ini adalah untuk memberi informasi kepada pembaca khususnya para perawat atau yang sedang mengikuti pendidikan keperawatan mengenai pentingnya perancanaan asuhan keperawatan sehingga asuhan keperawatan dapat dengan mudah dan cepat serta tepat untuk dilaksanakan 


\section{Daftar Pustaka}

Achmadi, L. D. (2015, Agustus). Gambaran Tingkat Pengetahuan Perawat dalam Penerapan

Standar Asuhan Keperawatan di Ruang Rawat Inap Interna RSUP Datoe Bhinangkang. ejournal Keperawatan,3.

Agustin, R. (2017). Optimalisasi Pelaksanaan Discharge Planning melelui Pengembangan Model Discharge Planning Terintegrasi Pelayanan Keperawatan. Jurnal Keperawatan Muhammadiyah, 2, 91-99.

Asmadi, 2008. Konsep Dasar Keperawatan. Jakarta : EGC

Butar-Butar, J., \& Simamora, R. H. (2016). Hubungan Mutu Pelayanan Keperawatan dengan Tingkat Kepuasan Pasien Rawat Inap di RSUD Pandan Kabupaten Tapanuli Tengah. Jurnal Ners Indonesia, 6(1), 50-63.

Dewi, Leni Kartika. (2019). Faktor-Faktor Yang Mempengaruhi Tingkat Keberhasilan Perencanaan Keperawatan Dalam Asuhan Keperawatan. Jurnal Keperawatan

Ginting, Ghea Karina Alemina. (2019). Pentingnya Perencanaan Sebagai Salah Satu Tahapan Proses Keperawatan. Jurnal Keperawatan

Potter, A., \& Perry, A. (2017). Buku Ajar Fundamental Keperawatan: Konsep, Proses, dan Praktik (4th ed.). Jakarta: Buku Kedokteran EGC

Sari, I. P. (2016). Hubungan Pengetahuan Perawat Tentang Model Asuhan Keperawatan Metode Tim Dengan Implementasinya Di Ruang Bedah Flamboyan Rsud Dr Soetomo Surabaya. Medica Majapahit, 8(2), 74-79.

Simamora, R. H. (2005). Hubungan Persepsi Perawat Pelaksana Terhadap Penerapan Fungsi Pengorganisasian Yang Dilakukan Oleh Kepala Ruangan Dengan Kinerjanya Diruang Rawat Inap RSUD Koja Jakarta Utara (Doctoral dissertation, Tesis FIK UI, Tidak dipublikasikan).

Tucker, S. M. (1998). Standar Perawatan Pasien: Proses Keperawatan, diagnosis, dan evaluasi. (Y. Asih, Ed.) Jakarta: EGC.

Wulandari Putri, Krianto, Yuyun. (2016). Faktor Faktor Yang Berhubungan Dengan Pendokumentasian Asuhan Keperawatan Di Rumah Sakit Jiwa. Ners Jurnal Keperawatan, Vol 12 No 2, 131-142

Yenny Randa, Andreas. (2014). Faktor - Faktor Yang Berhubungan Dengan Perawat Pelaksana Dalam Implementasi Asuhan Keperawatan.Jurnal Kesehatan Lentera Acitya,Vol 1 